\title{
Inappropriate complementary feeding practice increases risk of stunting in children aged 12-24 months
}

\author{
Hijra*, Siti Fatimah-Muis*, and Martha Irene Kartasurya**
}

\begin{abstract}
*Department of Nutrition, Faculty of Medicine, Diponegoro University Semarang ***Department of Public Health, Diponegoro University Semarang

Correspondence:

Hijra

Department of Nutrition,

Faculty of Medicine,

Diponegoro University

(Komplek Zona Pendidikan

RSUP Dr. Kariadi,

Gd. Dekanat FK Undip Lt.2)

Jl. Dr. Soetomo No. 18 Semarang Email:

hijratulmarahsubanrio@gmail.com

Univ Med 2016;35:146-55

DOI: 10.18051/UnivMed.2016.v35.146-155 pISSN: 1907-3062 / eISSN: 2407-2230

BACKGROUND

In 2013, the prevalence of stunting in Central Sulawesi province was $41 \%$, which was higher than the national prevalence of $37.2 \%$. Complementary feeding practice, infectious disease, history of exclusive breastfeeding, birth weight and birth length were assumed to contribute to the prevalence of stunting. The objective of the present study was to identify the risk factors for stunting among children aged 12 to 24 months.

\section{METHODS}

This study was conducted using a case control design. Subjects were children aged 12-24 months, consisting of 58 cases and 58 controls. Data were obtained with a body length infantometer. Data on complementary feeding practices, history of exclusive breastfeeding, and history of infectious diseases were obtained using questionnaires. Nutrient intakes were measured by semi quantitative food frequency questionnaires. Data on birth weight and birth length were obtained from the buku KIA (maternal and child health record). Data were analyzed by chi-square and logistic regression tests.
\end{abstract}

This open access article is distributed under a Creative Commons Attribution-Non Commercial-Share Alike 4.0 International License

\section{RESULTS}

There was no difference in sex, BMI, and parental education between cases and controls $(p>0.05)$. After controlling for history of exclusive breastfeeding and birth weight, the risk factors for stunting were inappropriate complementary feeding practice in terms of quantity and quality $(\mathrm{OR}=8.26$; 95\% CI: 2.69-25.44), history of diarrhea $(\mathrm{OR}=4.73$; 95\% CI: 1.08-20.69), birth length $(\mathrm{OR}=5.11 ; 95 \% \mathrm{CI}: 1.69-15.46)$ and respiratory tract infection $(\mathrm{OR}=5.30 ; 95 \% \mathrm{CI}: 1.03-27.23)$. Inappropriate complementary feeding practice was the most dominant factor for stunting.

\section{CONCLUSION}

Inappropriate complementary feeding practice increased the risk of stunting in 12-24 months old children by 8.26 . This study confirms the need to scale up interventions during the first 2 years of life, including appropriate infant feeding practices.

Keywords: Stunting, complementary feeding practices, diarrhea, children 12-24 months 


\section{INTRODUCTION}

Central Sulawesi is one of the provinces with prevalence rates of stunting above the national prevalence and its stunting prevalence rate is categorized as serious. ${ }^{(1)}$ The prevalence of stunting in the underfives in 2013 in Central Sulawesi was $41 \%$, with a prevalence of stunting in the underfives in Palu City of $35.5 \%$. Among the puskesmas (primary health centers) of Palu City, Puskesmas Sangurara has the relatively high prevalence of stunting of $50 \%$. $^{(2)}$

Complementary feeding practice is important contributes to the prevalence ofstunting. Complementary feeding that is of good quality and is quantitatively adequate is an important component in the diet of the underfives, since it contains contains macro- and micronutrients that affect linear growth. ${ }^{(3)}$ The age of 6 to 24 months is one of the most critical periods for linear growth, and is also the time of peak prevalence of stunting in developing countries, because of the high dietary requirements and the limited quality and quantity of complementary feeding. ${ }^{(4)}$ Complementary feeding refers to the introduction of safe and nutritious foods at the appropriate time. ${ }^{(5)}$ In general, studies on complementary feeding in areas of food shortages show that fortification with micronutrients has only slight or no impact on growth. Complementary feeding may increase linear growth and decrease stunting. ${ }^{(6)}$

Complementary feeding should preferably be adequate, safe, and appropriate to the age of the child. The period of introduction of complementary feeding that is coincident with the decrease in breastfeeding is the period of peak growth failure, nutrient deficiencies, and infectious diseases in children. ${ }^{(7-8)}$ According to Teshome et al. ${ }^{(9)}$ too early introduction to complementary carries a 1.1-fold risk of stunting, whereas too late introduction to complementary carries a 2.2-fold risk of stunting.

The present study on complementary feeding practice in differs from previous studies, in that it evaluated complementary feeding practice in terms of serving size (portion), provision of snacks, provision of foods of animal and vegetable origin, provision of formula milk, composition of the children's meals, food preparation and storage by the mothers, maternal behavior when the children refuse to eat, provision of breastfeeding, adequacy level of energy, protein, zinc, iron, and vitamin A from the complementary feeding, all of which were lacking in the previous sudies.

Infectious diseases that are associated with linear growth are diarrhea and respiratory tract infection, and result in longterm effects in the form of growth deficit in height. ${ }^{(10)}$ Infectious disease may be the cause of decreased dietary intake. Low dietary intake, decrease in nutrients as a result of vomiting, diarrhea, malabsorption and fever of long duration may cause nutrient deficiencies, and consequently infant and child growth and immune system abnormalities. ${ }^{(11)}$ Stunting is associated with respiratory disease and fever, because of increased metabolic requirements and decreased dietary intake during illness. ${ }^{(12)}$

The purpose of the present study was to analyze inappropriate complementary feeding practice and infectious diseases as risk factors for stunting in children aged 12-24 months.

\section{METHODS}

\section{Study design}

The design of the study was observational with non-matched case controls. This study was conducted in the catchment area of Puskesmas Sangurara, Palu City, Central Sulawesi, from February until April 2016.

\section{Study subjects}

The subjects of this study were underfives aged 12-24 months, totaling 116 children, consisting of 58 stunted and 58 non-stunted children. The number of study subjects was calculated for an unpaired case control analytic study with categorical variables, using the following formula:

$$
\mathrm{n}_{1}=\mathrm{n}_{2}=\frac{\left[\mathrm{Z} \alpha \sqrt{2 \mathrm{PQ}}+\mathrm{Z} \beta \sqrt{\mathrm{P}_{1} \mathrm{Q}_{1}+\mathrm{P}_{2} \mathrm{Q}_{2}}\right]^{2}}{\left(\mathrm{P}_{1}-\mathrm{P}_{2}\right)^{2}}
$$


Based on the number of study subjects from previous studies using odds ratio, ${ }^{(13-14)}$ the number of subjects for this study was 58 cases and 58 controls, so that the total number of subjects was 116.

The diagnosis of stunting was established by health personnel at Puskesmas Sangurara. Recruitment of the subjects was by consecutive non-random sampling. The inclusion criteria in this study were: children aged 12-24 months, having a height-to-age ratio of less than -2 SD for the cases and $\geq-2$ SD for the controls, with recorded birth weights and lenghts, living with both parents, and residing in the catchment area of Puskesmas Sangurara. The exclusion criteria were: children with physical or congenital disabilities, and children who were ill and had to be hospitalized during the study.

\section{Measurements}

Data on body length were obtained by means of an infantometer and were categorized into stunting and normal. Data on complementary feeding practice in terms of quality, maternal knowledge and sanitation and hygiene, history of exclusive breastfeeding, and history of infectious diseases were obtained through interviews using structured questionnaires. Data on complementary feeding practice in terms of quantity, i.e. nutrient intake from complementary feeding, were obtained using semiquantitative food frequency questionnaires. Adequacy of nutrient intakes were determined from the daily dietary intake of the children as compared with Indonesian recommended dietary allowances (IRDA). The nutrient intakes under study were adequacy level of energy, protein, zinc, iron, and vitamin A from the complementary feeding. The data on complementary feeding practice, which were obtained from 18 questions, were subsequently categorized into appropriate (total score $=1-14$ ) and inappropriate (total score $=15-28$ ). Data on birth weight and birth length were obtained from the buku KIA ( maternal and child health record). Data on birth weight were categorized into low birth weight if the birth weight was <2500 grams and normal if the birth weight was $\geq 2500$ grams. In addition, birth length was categorized as short if the birth length was $<48 \mathrm{~cm}$ and normal if the birth length was $\geq 48 \mathrm{~cm}$.

\section{Data analysis}

The data analysis used the chi-square test and significance level á of $\leq 0.05$ and the odds ratio (OR). Multivariate analysis by means of multiple logistic regression was used to determine the most dominant factors for stunting.

\section{Ethical clearance}

This study obtained ethical clearance from the Ethics Commission, Faculty of Medicine, Diponegoro University, Semarang in February 2016.

\section{RESULTS}

Complementary feeding practice was evaluated from several aspects, i.e. age of introduction of complementary feeding, frequency of provision, variety, servings (portions), provision of snacks, provision of animal and vegetable foods, provision of formula milk, composition of meals, food procurement and storage by the mothers, maternal behavior when the children refuse to eat, breastfeeding, and adequacy levels of energy, protein, zinc, iron, and vitamin A from the complementary feeding. The frequency distribution based on the 18 evaluation aspects of complementary feeding practice in terms of quality and quantity, may be seen in Table 1 , and the distribution of maternal knowledge and sanitation and hygiene in Table 2.

Table 1 shows the evaluation aspects of complementary feeding in terms of quality and quantity. With regard to quality, between the cases and controls there was a difference in the frequency of complementary feeding, variety, portion size, provision of snacks, provision of animal and vegetable foods, provision of formula milk, and composition of meals $(\mathrm{p}<0.05)$. With regard to quantity, between the cases and controls there was a difference in the adequacy levels for 
Table 1. Distribution of complementary feeding practice in terms of quality and quantity

\begin{tabular}{|c|c|c|c|}
\hline Complementary feeding practice & Cases $(n=58)$ & Controls $(n=58)$ & $\mathbf{p}$ \\
\hline Fre quency of complem entary feeding & & & 0.001 \\
\hline$<3$ tim es daily & $32(55.2)$ & $14(24.1)$ & \\
\hline$\geq 3$ tim es daily & $26(44.8)$ & $44(75.9)$ & \\
\hline V ariety of complementary fe eding & & & 0.0001 \\
\hline Not varied & $30(51.7)$ & $6(103)$ & \\
\hline Occasionally varied & $24(41.4)$ & $17(29.3)$ & \\
\hline Varied & $4(6.9)$ & $35(60.3)$ & \\
\hline Portion size of $\mathrm{cam}$ plementary fee ding & & & 0.0001 \\
\hline Less than $1 / 2$ portion & $13(22.4)$ & $1(1.7)$ & \\
\hline $1 / 2$ to $3 / 4$ portion & $28(48.3)$ & $15(25.9)$ & \\
\hline One portion & $17(29.3)$ & $42(72.4)$ & \\
\hline Provision of snacks & & & 0.0001 \\
\hline Not provided & $30(51.7)$ & $3(5.2)$ & \\
\hline Occasionally provided & $18(31.0)$ & $13(22.4)$ & \\
\hline Regularly prowi ded & $10(17.2)$ & $42(72.4)$ & \\
\hline Provision of vegetable food & & & 0.0001 \\
\hline Not provided & $21(36.2)$ & $2(3.4)$ & \\
\hline Occasionally provided & $29(50.0)$ & $19(32.8)$ & \\
\hline Regularly provi ded & $8(13.8)$ & $37(63.8)$ & \\
\hline Provision of animal food & & & 0.0001 \\
\hline Not provided & $19(32.8)$ & $1(1.7)$ & \\
\hline Occasionally provided & $27(46.6)$ & $14(24.1)$ & \\
\hline Regularly prowi ded & $12(20.7)$ & $43(74.1)$ & \\
\hline Provision of formula milk & & & 0.0001 \\
\hline Not provided & $23(39.7)$ & $4(6.9)$ & \\
\hline Occasionall y provided & $27(46.6)$ & $32(55.2)$ & \\
\hline Regularly prowi ded & $8(13.8)$ & $22(37.9)$ & \\
\hline Composition of meals & & & 0.0001 \\
\hline Rice only & $14(24.1)$ & $2(3.4)$ & \\
\hline Rice + meat $\alpha$ rice + vegetables & $32(55.2)$ & $13(22.4)$ & \\
\hline Rice + meat + vegetables & $12(20.7)$ & $43(74.1)$ & \\
\hline Adequacy 1 eve1 for energy & & & 0.002 \\
\hline Inadequate if $<90 \%$ & $40(69.0)$ & $19(32.8)$ & \\
\hline Adequate if $\geq 90 \%$ & $18(31.0)$ & $39(67.2)$ & \\
\hline Adequacy level for protein & & & 0.0001 \\
\hline Inadequate if $<90 \%$ & $40(69.0)$ & $30(51.7)$ & \\
\hline Adequate if $\geq 90 \%$ & $18(31.0)$ & $28(48.3)$ & \\
\hline Adequacy level for $z$ inc & & & 0.003 \\
\hline Inadequate if $<90 \%$ & $38(65.5)$ & $28(48.3)$ & \\
\hline Adequate if $290 \%$ & $20(34.5)$ & $30(51.7)$ & \\
\hline Adequacy level for ir on & & & 0.0001 \\
\hline Inadequate if $<90 \%$ & $42(72.4)$ & $30(51.7)$ & \\
\hline Adequate if $290 \%$ & $16(27.6)$ & $28(48.3)$ & \\
\hline Adequacylevel for vitamin $A$ & & & 0.0001 \\
\hline Inadequate if $<90 \%$ & $36(62.1)$ & $7(12.1)$ & \\
\hline Adequate if $\geq 90 \%$ & $22(37.9)$ & $51(87.9)$ & \\
\hline
\end{tabular}

energy, protein, iron, zinc, and vitamin A from the complementary feeding $(\mathrm{p}<0.05)$.

Table 2 shows the evaluation aspects of complementary feeding in terms of maternal konwledge and sanitation and hygiene. With regard to maternal knowledge, there was a difference in age of introduction of complementary feeding between cases and controls $(\mathrm{p}<0.05)$. However, between cases and controls there was no difference in maternal behavior when the child refuses to eat and in breastfeeding ( $p>0.05)$. With regard to sanitation and hygiene, between cases 
Table 2. Distribution of complementary feeding practice in terms of maternal knowledge and sanitation and hygiene

\begin{tabular}{|c|c|c|c|}
\hline Complementary feeding p ractice & Cases (n=58) & Contros $(n=58)$ & $\mathbf{p}$ \\
\hline Age of introduction of complem entary feeding & & & 0.001 \\
\hline$>6 \mathrm{~m}$ onths & $12(20.7)$ & $7(12.1)$ & \\
\hline$<6 \mathrm{~m}$ onths & $35(60.3)$ & $22(37.9)$ & \\
\hline 6 months & $11(19.0)$ & $29(50.0)$ & \\
\hline Maternal behavia when child refises to eat & & & 0.845 \\
\hline Left alone & $20(34.5)$ & $10(17.2)$ & \\
\hline Persuaded and served bit by bit & $38(65.5)$ & $48(82.8)$ & \\
\hline Breastfeeding & & & 0.184 \\
\hline None & $26(44.8)$ & $18(31.0)$ & \\
\hline Regular & $32(55.2)$ & $40(69.0)$ & \\
\hline Preparation of complementary food by mother & & & 0.145 \\
\hline $\begin{array}{l}\text { More frequently purchased from shops/market and } \\
\text { seldom self-prepared }\end{array}$ & $9(15.5)$ & $5(8.6)$ & \\
\hline Occasionally self-prepared/cooked & $26(44.8)$ & $23(39.7)$ & \\
\hline Fr equently self-prepared/cooked & $23(39.7)$ & $30(51.7)$ & \\
\hline Storage of complem entary food & & & 0.072 \\
\hline Left exposed without cover & $8(13.8)$ & $3(5.2)$ & \\
\hline Left exposed under cover & $31(53.4)$ & $21(36.2)$ & \\
\hline Stcred in a safe, clean, and covered place (eg, pantry) & $19(32.8)$ & $34(58.6)$ & \\
\hline
\end{tabular}

and controls there was no difference in preparation and storage of complementary food by mothers $(\mathrm{p}>0.05)$.

Table 3 shows that there were more children with inappropriate complementary feeding practice in the group of cases $(79.3 \%)$ than in the control group $(24.1 \%)$. Mothers with inappropriate complementary feeding practice carried a risk of stunting that was 12.04-fold greater than those with appropriate complementary feeding practice $(\mathrm{OR}=12.04 ; 95 \%$ CI: 5.02-28.89). There were more children suffering from URI in the last 2 months in the group of cases $(70.7 \%)$ than in the control group (20.7\%). Children suffering from URI in the last 2 months had a 9.24 times greater risk of stunting when compared with those not suffering from URI in the last 2 months (OR=9.24; 95\% CI: 3.9521.64). There were more children suffering from diarrhea in the last 2 months in the group of cases $(56.9 \%)$ than in the control group $(10.3 \%)$. Children suffering from diarrhea in the last 2 months had a 11.44 times greater risk of stunting when compared with those not suffering from diarrhea in the last 2 months $(\mathrm{OR}=11.44 ; 95 \%$ CI: 4.24-30.85). There were more children without exclusive breastfeeding in the group of cases $(81.0 \%)$ than in the control group $(50.0 \%)$. Children without exclusive breastfeeding had a 4.27 times greater risk of stunting when compared to children with exclusive breastfeeding (OR=4.27; 95\% CI: 1.85-9.84).

Children of low birth weight had a 5.16 times greater risk of stunting in comparison with those of normal birth weight $(\mathrm{OR}=5.16$; 95\% CI: 1.77 15.03). Children with a birth length of $<48 \mathrm{~cm}$ had a 6.91 times greater risk of stunting in comparison with those with a birth length of $\geq 48$ $\mathrm{cm}(\mathrm{OR}=6.91 ; 95 \%$ CI: 3.05-15.62).

The variables tested in the multiple logistic regression analyis were complementary feeding practice, history of URI, history of diarrhea, history of exclusive breastfeeding, birth weight, and birth length. The results of the multiple logistic regression analysis may been seen in Table 4. The results show that the variables that constituted risk factors for stunting in children aged 12-24 months were complementary feeding practice, history of diarrhea, history of URI, and birth length. The most dominant risk factor was inappropriate complementary feeding practice (OR=8.26; 95\% CI: 2.69-25.44). 
Table 3. Crude odds ratis with $95 \%$ confidence interval limits for stunting in children aged 12-24 months

\begin{tabular}{|c|c|c|c|c|}
\hline Variable & $\begin{array}{l}\text { Cases } \\
(\%)\end{array}$ & $\begin{array}{c}\text { Controls } \\
(\%)\end{array}$ & $\mathbf{p}$ & OR $(95 \% \mathrm{CI})$ \\
\hline \multicolumn{5}{|l|}{ Complem entary feeding practice } \\
\hline Inappropriate & $46(79.3)$ & $14(24.1)$ & 0.0001 & 12.04 \\
\hline Appropriate & $12(20.7)$ & $44(75.9)$ & & $(5.02-28.89)$ \\
\hline \multicolumn{5}{|l|}{ History of upper respir atory tract infections (URI) } \\
\hline $\begin{array}{l}\text { Suffers from URI if attacked } \geq 3 \text { times in last } 2 \\
\text { months }\end{array}$ & $41(70.7)$ & $12(20.7)$ & 0.0001 & $\begin{array}{c}9.24 \\
(3.95-21.6)\end{array}$ \\
\hline $\begin{array}{l}\text { Not suffering from URI if attacked }<3 \text { times in } \\
\text { last } 2 \mathrm{~m} \text { onths }\end{array}$ & $17(29.3)$ & $46(79.3)$ & & \\
\hline \multicolumn{5}{|l|}{ History of diarthea } \\
\hline $\begin{array}{l}\text { Suffers from diarthea if attacked } \geq 3 \text { times in last } \\
2 \text { months }\end{array}$ & $33(56.9)$ & $6(10.3)$ & 0.0001 & $\begin{array}{c}11.44 \\
(4.24-30.85)\end{array}$ \\
\hline $\begin{array}{l}\text { Not suffering from URI if attacked }<3 \text { times in } \\
\text { last } 2 \text { months }\end{array}$ & $25(43.1)$ & $52(89.7)$ & & \\
\hline \multicolumn{5}{|l|}{ History of ex clusive breastfeeding } \\
\hline No & $47(81.0)$ & $29(50.0)$ & 0.001 & 4.27 \\
\hline Yes & $11(19.0)$ & $29(50.0)$ & & $(1.85-9.84)$ \\
\hline \multicolumn{5}{|l|}{ Birth weight } \\
\hline Low, $<2500 \mathrm{gram}$ & $19(32.8)$ & $5(8.6)$ & 0.003 & 5.16 \\
\hline Norm al, $\geq 2500 \mathrm{gam}$ & $39(67.2)$ & $53(91.4)$ & & $(1.77-15.03)$ \\
\hline \multicolumn{5}{|l|}{ Birth length } \\
\hline Shott, $<48 \mathrm{~cm}$ & $43(74.1)$ & $17(29.3)$ & 0.0001 & 6.91 \\
\hline Norm al, $\geq 48 \mathrm{~cm}$ & $15(25.9)$ & $41(70.7)$ & & $(3.05-15.26)$ \\
\hline
\end{tabular}

\section{DISCUSSION}

The frequency of complementary feeding in children with stunting tended to be lower than in normal children. The food frequency in children with stunting was very low and several subjects were found who had only one meal daily, in contrast to normal children who had 3 to 4 meals daily. This is in line with a study in Nepal showing that a food frequency of less than 4 times daily was a risk factor of stunting, in which the children who had fewer than 4 meals daily carried a 3.60 times greater risk of stunting. ${ }^{(15)}$ The majority of children with stunting did not consume a variety of foods. Several subjects consumed only complementary foods of a certain brand and breast milk since the age of 6 months until 1 year. Similar to the study in Nepal, the present study shows that children with lower than the standard food variety had a 4.06 times greater risk of stunting. ${ }^{(15)}$ The portion size in children with stunting tended to be smaller than in normal children. The results of our study shows that the majority of children with stunting consumed less than $1 / 2$ portion at each meal, in contrast to normal children, most of whom consumed 1 full portion at each meal. These study results also show that normal children had more frequent snacks than children with stunting. Most of the children with stunting were given a main dish of rice porridge or steamed rice,

Table 4. Results of multiple logistic regression analysis

\begin{tabular}{lcccc}
\hline & P & OR & \multicolumn{2}{c}{ 95\%CI } \\
\hline Compl em entary feeding practice & 0.0001 & 8.26 & 2.69 & 25.44 \\
History of URI & 0.046 & 5.30 & 1.03 & 27.24 \\
Birth length & 0.004 & 5.11 & 1.69 & 15.46 \\
History of diarthea & 0.039 & 4.73 & 1.08 & 20.69 \\
History of ex clusive breastfeeding & 0.846 & 5.97 & 0.16 & 4.57 \\
Birth weight & 0215 & 2.84 & 0.55 & 14.78 \\
\hline
\end{tabular}


alternated only with breastfeeding, whereas normal children were given snacks such as biscuits of two popular brands. At the age of 12-24 months, the combination of breastfeeding and main dish only is inadequate to meet the energy requirements of the children for optimal growth, for which additional feeding is required such as snacks in the form of fruits or biscuits that contain adequate amounts of nutrients. ${ }^{(16)}$

Complementary feeding practice was also viewed from the aspect of composition of the meals. Table 1 shows that the majority of subjects only consumed rice and fish without vegetables. This was due to the fact that these children did not like vegetables. Several subjects were also found to consume only rice and vegetables without fish, because they did not like fish. However, there were also subjects who consumed rice only without fish or vegetables. The parents preferred to give sugar water, tea, and even coffee to their children. Some children even received sugar water 3 times daily. The reason given by the parents was that their children did not like milk and that they could not afford to buy formula milk for their children, because of their low economic status. Some subjects were also found who were not breastfed from the age of less than 1 year.

The low adequacy level for energy was more frequent in children with stunting than in normal children. The present study is in line with a study on children aged 6-24 months in Penanggalan District, Subulussalam City, Aceh Province, which found that a low level of adequacy for energy was a risk factor of stunting. Stunting occurs more frequently in children with a low adequacy level for energy. ${ }^{(13)}$

The proportion of children with stunting was also higher in children with low adequacy level for protein. A study on children aged 2-5 years in Kenya and Nigeria found that inadequate protein intake was associated with stunting. ${ }^{(17)}$ The low level of adequacy for protein in children with stunting in the our study was caused by inadequate consumption of fish, chicken, and beef, which are highly adequate sources of animal protein. Some subjects only consumed fish once weekly, chicken once a month or at longer intervals, and beef once a year. In addition, vegetable protein was also occasionally consumed, because some children did not like to consume vegetables and fruits in adequate amounts (data not presented).

The present study also shows that the proportion of children with stunting was higher in children with low adequacy levels for zinc. A study in Klungkung District in children aged 2460 months showed that low zinc level was a risk factor of stunting. The risk of stunting in children with zinc deficiency was 16.1 -fold. ${ }^{(18)}$ The low adequacy level of zinc in children with stunting was caused by the low intake of foods with adequate zinc content, such as amaranth, fish and meat. The intake of iron was also exceedingly low in the group of children with stunting in comparison with normal children. This was caused by inadequate consumption of foods that are sources of iron, such as meat and fish.

Vitamin A is one of the important nutrients for growth. Vitamin A deficiency causes children to be vulnerable to disease, so that their body defenses are reduced and their dietary intake becomes irregular. Table 1 shows that the proportion of children with stunting was higher in children with low adequacy levels of vitamin A. A study in Kenya in children aged 24-35 months found that the prevalence of stunting was $50 \%$ higher in children who did not consume vitamin A supplements, in comparison with children who did. ${ }^{(19)}$

The present study found that too early or too late introduction of complementary feeding was more frequent in children with stunting than in normal children. A study in Ethiopia in children aged 0-59 months showed that children with delayed complementary feeding had a 2.2 times greater risk of stunting, whereas too early introduction of complementary feeding had a 1.1 times greater risk of stunting. ${ }^{(20)}$ The role of the mothers is very important in determining the nutritional status of their children, such as when the children have their meals, the mothers should pay attention to what is consumed by the children. Some mothers only let their children cry or play 
when they refuse to eat, so that the portions consumed are very small, and some subjects were even found to consume 2-3 spoonful only. This is due to the fact that their mothers do not like their children to cry when given food and are afraid that their children will vomit when forced to eat. But some mothers persuade their children when they refuse to eat by giving them the food bit by bit so that their children will consume some.

Regarding the storage of the prepared food, in the group of children with stunting the food was more frequently left exposed in the covers, whereas in normal children, the mothers more frequently stored the food in a closed and clean place such as a pantry. Storing food while letting them remain exposed may result in bacterial contamination of the food so that it may become a health hazard for the children.

Complementary feeding practice was more frequently inadequate in terms of quality and quantity, in comparison with maternal knowledge and sanitation and hygiene. The results of the present study are consistent with those of a study in Banda Aceh City on children aged 12-60 months, showing that children with inadequate complementary feeding had a 3.4 times greater risk of stunting. ${ }^{(14)}$ Nutrient intake plays an essential role in the growth process of children, so that to achieve optimal growth and development, nutrient intakes have to be met. By the age of 6 months, exclusive breastfeeding does not adequately meet the nutrient requirements of the children, so that additional sources of nutrients are needed from complementary feeding.

Provision of foods with inadequate nutrient intake, exceedingly low frequency of meals and portion size constitute the main causes of poor nutritional status in children. Complementary feeding must provide sources of macro- and micronutrients that play a role in linear growth in the underfives. Food variety is also very important in maintaining the nutritional status of children. Some subjects were found to consume only a single type of food even for a period of one week. In our study area, there is a special type of vegetable dish, namely Moringa oleifera leaves (daun kelor) in coconut milk (santan), which is the type of vegetable dish most frequently consumed by the children. Some children in one week consume only kelor leaves and rice without other foods.

Several evaluation aspects of complementary feeding practice that have been explained are essential in determining the quality and quantity of the provided complementary feeding. This is the reason why children with inappropriate complementary feeding practice have a 12.37 times greater risk of stunting. The risk of stunting in our study area was greater that that in previous studies. The prevalence of stunting may hopefully decrease to $20 \%$ (amounting to 127 million children) in 2025, which is the target of the World Health Assembly. ${ }^{(20)}$ If the specific nutritional intervention package (provision to the mothers of folic acid, calcium, micronutrients, balanced protein and energy supplements, and promotion of breastfeeding and appropriate complementary feeding) will have been increased for a coverage of $90 \%$, stunting will decrease and consequently also the mortality rate of the underfives. ${ }^{(21)}$

Children with URI in the last 2 months were more numerous in the group of cases than in the group of controls. The present study is in accord with a study in Kupang, showing that children with a history of infectious disease had a greater probability of stunting than children without a history of infectious disease. Stunting is associated with infectious disease, since during an illness the metabolic requirements increase, whereas the dietary intakes decrease, resulting in disturbed growth. ${ }^{(22)}$ A history of diarrhea in the last 2 months was more frequent in the group of cases than in the group of controls. This study agrees with a study in Nepal showing that diarrhea is a risk factor of stunting, where children with diarrhea have a 7.46 times greater risk of stunting. ${ }^{(15)}$ Diarrhea is associated with growth failure because of the occurrence of malabsorption of nutrients when the children have diarrhea. The age of 2 years is the age at which infectious diseases such as diarrhea carry an extremely high risk of stunting. ${ }^{(23)}$ 
Children without exclusive breastfeeding were more numerous in the group of cases than in the group of controls. This study is similar to a study in Ethiopia which showed that children with less than 6 months of breastfeeding had a greater risk of stunting than children with exclusive breastfeeding during the first 6 months. ${ }^{(24)} \mathrm{A}$ study in Nepal showed that children who did not receive colostrum had a 3.40 times greater risk of stunting. ${ }^{(13)}$

Low birth weight infants tend to have intrauterine growth retardation because of poor maternal nutrition. Low birth weight infants with subsequent inadequate nutrient intakes frequently have childhood infections in the growth period so that the growth of these children is retarded and ultimately results in stunting. These results are in agreement with those of a study in Semarang City, in that low birth weight is a risk factor of stunting in children aged 1-2 years. Children with a history of low birth weight have a 11.2 times greater risk of stunting than children with normal birth weight. ${ }^{(25)}$ Short birth length was more frequent in the group of cases than in the group of controls. This is in line with a study conducted in Bogor District in 2013 on children aged 12 months, where it was found that birth length significantly affects stunting in children aged 12 months. ${ }^{(26)}$

The most dominant risk factor of stunting in children aged 12-24 months in Palu City, Central Sulawesi, was inappropriate complementary feeding practice in terms of quantity and quality. After controlling for the variables of history of exclusive breastfeeding and birth weight, the variables of birth length, complementary feeding practice, history of URI and history of diarrhea constituted the risk factors of stunting in children aged 12-24 months in Palu City, Central Sulawesi.

In the present study, the risk factors of stunting that were studied were only complementary feeding practice and adequacy levels of nutrients from complementary feeding, determined by means of semiquantitative FFQ. This method carries informational bias (recall bias) since it is exclusively based on the capacity to remember. Some mothers forgot what were the foods usually consumed by their children, so that they had to be questioned repeatedly.

For health personnel, there is a need for improved dissemination of information in the form of health education to mothers of underfives on the quality and quantity of complementary feeding that is appropriate for consumption by children in their growth period so that it may prevent the risk of growth failure and deficiencies of certain nutrients that may be detrimental to the development of health and mental capacity of the children. In addition, health personnel need to improve dissemination of information to mothers of underfives so that they always practice behaviors of clean and healthy living (perilaku hidup bersih and sehat, PHBS) to prevent the occurrence of infectious diseases, especially by maintaining food hygiene so that it may not be easily contaminated by bacteria.

\section{CONCLUSION}

Inappropriate complementary feeding practice was the must dominant risk factor of stunting in children aged 12-24 months old. This study confirms the need to scale up interventions during the first 2 years of life, including appropriate infant feeding practices.

\section{CONFLICT OF INTEREST}

The authors declare that they have no conflict of interest with regard to the present study.

\section{ACKNOWLEGMENTS}

We thank the Head and staff of Puskesmas Sangurara, Palu City, Central Sulawesi, who allowed us to conduct the study and obtain data at their Puskesmas. Thanks are also due to the parents of the study subjects for their cooperation in this study.

\section{REFERENCES}

1. Kementerian Kesehatan Republik Indonesia (Kemenkes RI). Riset Kesehatan Dasar 
(Riskesdas) tahun 2010. Jakarta: Kementerian Kesehatan Republik Indonesia;2010.

2. Dinas Kesehatan Provinsi Sulawesi Tengah. Laporan pemantauan status gizi (PSG) tahun 2013. Palu: Dinas Kesehatan Provinsi Sulawesi Tengah;2013.

3. Dewey KG, Adu-Afarwuah S. Systematic review of the efficacy and effectiveness of compementary feeding interventions in developing countries. Matern Child Nutr 2008;4:24-85.

4. Shrimpton R, Victora CG, de Onis M, et al. Worldwide timing of growth faltering: implications for nutritional interventions. Pediatrics 2001;107:1-7.

5. World Health Organization (WHO). Implementing the global strategy for infant and young child feeding. Geneva: World Health Organization;2003.

6. Lassi ZS, Das JK, Zahid G, et al Impact of education and provision of complementary feeding on growth and morbidity in children less than 2 years of age in developing countries: a systematic review. BMC Public Health 2013; 13:1-10.

7. Victora CG, de Onis M, Hallal PC, et al. Worldwide timing of growth faltering: revisiting implications for interventions. Pediatrics 2010; 125: 473-480.

8. Black RE, Allen LH, Bhutta ZA, et al. Maternal and child undernutrition: global and regional exposures and health consequences. Lancet 2008;371:243-60.

9. Teshome B, Kogi-Makau W, Getahun Z, et al. Magnitude and determinants of stunting in children under-five years of age in food surplus region of Ethiopia: the case of West Gojam Zone. Ethiop J Health Dev 2009;23:98-106.

10. Dewey KG, Mayers DR. Early child growth: how do nutrition and infection interact? Maternal Child Nutr 2011;7:129-42.

11. Adeladza AT. The influence of socio-economic and nutritional characteristics on child growth in Kwale district of Kenya. Afr J Food Agric Nutr Dev 2009;9:1570-90.

12. Weisz A, Meuli G, Thakwalakwa C, et al. The duration of diarrhea and fever is associated with growth faltering in rural Malawian children aged 6-18 months. Nutr J 2011;10:1-4.

13. Lestari W, Margawati A, Rahfiludin MZ. Faktor risiko stunting pada anak umur 6-24 bulan di kecamatan Penanggalan Kota Subulussalam Provinsi Aceh. J Gizi Indonesia 2014;3:126-34.

14. AL-Rahmad AH, Miko A, Hadi A. Kajian stunting pada anak balita ditinjau dari pemberian ASI eksklusif, MP-ASI, status imunisasi dan karakteristik keluarga di Kota Banda Aceh. J Kesehatan Ilmiah Nasuwakes 2013;6:169-84.

15. Paudel R, Pradhan B, Wagle RR, et al. Risk factors for stunting among children: a community based case control study in Nepal. Kathmandu University Medical J 2012;10:1824.

16. Imdad A, Yakoob MY, Bhutta ZA. Impact of maternal education about complementary feeding and provision of complementary foods on child growth in developing countries. BMC Public Health 2011;11:1-14.

17. Stephenson K, Amthor R, Mallowa S, et al. Consuming cassava as a staple food places children 2-5 years old at risk for inadequate protein intake, an observational study in Kenya and Nigeria. Nutr J 2010;9:1-6.

18. Mardewi KW. Kadar seng serum rendah sebagai faktor risiko perawakan pendek pada anak (Tesis). Denpasar: Universitas Udayana;2014.

19. Kimane-Murage EW, Ndedda C, Raleigh K, et al. Vitamin A supplementation and stunting levels among two year olds in Kenya: evidence from the 2008-09 Kenya Demographic and Health Survey. Int J Child Health Nutr 2012;1: 135-47.

20. Black RE, Victora CG, Walker SP, et al. Maternal and child undernutrition and overweight in lowincome and middle-income countries. Lancet 2013;382:427-51.

21. Bhutta ZA, Das JK, Rizvi A, et al. Evidence based interventions for improvement of maternal and child nutrition: what can be done and at what cost? Lancet 2013;382:452-77.

22. Picauly I, Toy SM. Analisis determinan dan pengaruh stunting terhadap prestasi belajar anak sekolah di Kupang dan Sumba Timur, NTT. J Gizi Pangan 2013;8:55-62.

23. Dewey KG, Mayers DR. Early child growth: how do nutrition and infection interact?. Matern Child Nutr 2011;7:129-42.

24. Fikadu T, Assegid S, Dube L. Factors associated with stunting among children of age 24 to 59 months in Meskan district, Gurage Zone, South Ethiopia: a case-control study. BMC Public Health 2014;14:1-7.

25. Candra A, Puruhita N, Susanto JC. Risk factors of stunting among 1-2 years old children in Semarang City. Media Medika Indonesiana 2011;45:206-12.

26. Ernawati F, Rosmalina Y, Permanasari Y. Pengaruh asupan protein ibu hamil dan panjang badan bayi lahir terhadap kejadian stunting pada anak usia 12 bulan di Kabupaten Bogor. Penelitian Gizi Makanan 2013;36:1-11. 